Paedagogia Christiana

I/27 (20I I) - ISSN 1505-6872

Matgorzata Kowalczyk*

Teresa Łacka**

Toruń

\title{
Przemoc i jej mechanizmy w związkach partnerskich
}

Przemoc towarzyszy człowiekowi od zarania dziejów. Analiza tekstów historycznych dobitnie potwierdza występowanie przemocy i wskazuje na różne jej interpretacje w zależności od okresu czasowego i kultury. Dociekania badaczy z całego świata wskazują, jak bardzo powszechna stała się przemoc, nieznająca granic społecznych, etnicznych, ekonomicznych, kulturowych, religijnych, geograficznych ${ }^{1}$. Ta wielość problemu sprawia, że potrzeba badania przemocy wydaje się nieodzowna. Dla lepszego zrozumienia zjawiska konieczne wydaje się także traktowanie jej w sposób interdyscyplinarny, uwzględniając perspektywy: prawną, moralną, społeczną i psychologiczną dla zapobiegania zjawiska, ale też w celu szeroko rozumianej edukacji społecznej. Spojrzenie interdyscyplinarne na przemoc pozwala uznać ją za przestępstwo, które podlega sankcjom karnym. Pozwala też traktować ją jako zło moralne, gdzie niezbędne staje się udzielanie pomocy oraz opieki nad ofiarami przemocy. Eksploracja wiedzy oraz zwracanie uwagi na zjawisko i mechanizmy przemocy dają możliwość również szerszego oddziaływania na sprawcę przemocy, chociażby w aspekcie wychowawczym i resocjalizacyjnym, które w ostateczności mogłoby powstrzymać go od dal-

* Mgr Małgorzata Kowalczyk, mgr psychologii, doktorant na Wydziale Nauk Pedagogicznych Uniwersytetu Mikołaja Kopernika w Toruniu.

** Mgr Teresa Łącka, mgr psychologii, pracownik Stowarzyszenia „Azyl” na Rzecz Pomocy Kobietom i Dzieciom Ofiarom Przemocy; Ośrodek Pomocy dla Osób Pokrzywdzonych Przestępstwem przy Ministerstwie Sprawiedliwości.

1 J. K. James, B. E. Gilliland, Strategie interwencji kryzysowej, Warszawa 2009, s. 237. 
szych zachowań przemocowych bądź uczyć zachowań alternatywnych. Rozpatrywane zaś i analizowane obyczaje i postawy zachowań przemocowych mogą stać się początkiem wypracowywania skutecznych metod profilaktyki, interwencji i pomocy socjalnej.

Zjawisko przemocy w związkach nie jest marginalne i nie dotyczy wyłącznie związków zalegalizowanych. Zdarza się bowiem, że opisywane zjawisko ma miejsce także w związkach dwojga ludzi, którzy nie są małżeństwem, ale uważają siebie za parę. Niejednokrotnie rozgrywając się w zaciszu domowym, zamyka ofiarę w cierpieniu umożliwiając sprawcy dalsze działanie. Opinię publiczną często bulwersuje fakt, że maltretowanie trwało latami, że nikt nie przerwał eskalacji krzywd. Należy przy tym mieć świadomość, że czynniki pozostawania w takim związku mają charakter złożony, wzajemnie zazębiają się. Nie ma prostej odpowiedzi na pytanie o powody.

Autorki tekstu podjęły się przybliżenia sytuacji, w jakiej znajduje się osoba doznająca przemocy, oraz charakterystyki typowych mechanizmów przemocy. Tekst jest próbą analizy zjawiska przemocy występującego w związkach małżeńskich, ale też związków partnerskich nieformalnych, pozostających we wzajemnym pożyciu. Tekst opisuje specyficzne interakcje, jakie mogą mieć miejsce w relacji: sprawca-ofiara w kontekście zachowań przemocowych. Wydaje się, że pogłębianie świadomości społecznej i state uczulanie na tego typu zjawiska, dziejącego się w rodzinach, umożliwia konstruowanie skutecznych systemów pomocy i wsparcia osób uwikłanych w przemoc ${ }^{2}$.

\section{Definicja i formy przemocy}

Jak zaznaczono wcześniej, nie istnieje uprzywilejowana populacja, której nie dotyczyłoby zjawisko przemocy. Każdy znalazł się lub znajdzie w roli świadka, ofiary bądź sprawcy przemocy. Dotychczasowe badania dostarczają dowodów, że najczęściej osobami doznającymi przemocy są dzieci, kobiety, ludzie starsi i osoby niepełnosprawne ${ }^{3}$. Wśród obszarów będących w kręgu szczególnego zainteresowania naukowców, znajdują się akty krzywdzenia rozgrywające się w środowisku rodzinnym, w tym przemoc między dorosłymi partnerami. W literaturze na określenie przemocy w związku używane są następujące terminy: wzajemna przemoc w parze (common cuple violen-

${ }^{2}$ L. Mellibruda, Wybrane problemy patologii zycia rodzinnego, w: J. Strelau (red.), Psychologia. Podręcznik akademicki. Jednostka w spoleczeństwie i elementy psychologii stosowanej, t. 2, Gdańsk 2003, s. 756.

${ }^{3}$ M. Lakowska, W. Paszkiewicz, A. Wiechcińska, Wyprawa Pomoc. Poradnik dla osób doznajacych przemocy w rodzinie, Warszawa 2008, s. 21. 
ce), przemoc $\mathrm{w}$ związku partnerskim (couple violence, mutual violence), a w węższym znaczeniu: przemoc małżeńska (marital violence, spousal violence $)^{4}$. Raporty z badań dowodza, że przemoc wobec partnera w jakimś momencie trwania związku ma miejsce w 25-28\% par małżeńskich ${ }^{5}$. Szacuje się również, że w tych rodzinach, gdzie dochodzi do krzywdzenia, w ponad połowie par ma ono charakter wzajemny, w 1/4 to kobieta jest ofiarą i w około 1/4 mężczyzna doświadcza przemocy. Między kobietami i mężczyznami zaznaczają się niewielkie różnice, jeżeli chodzi o stosowanie łagodniejszych form przemocy. Trzeba jednak pamiętać, że rzeczywisty rozmiar zjawiska nigdy nie zostanie poznany z uwagi na nieujawnianie przez ofiary aktów krzywdzenia.

W Programie Przeciwdziałania Przemocy w Rodzinie prowadzonym przez Państwową Agencję Rozwiązywania Problemów Alkoholowych przyjęto następująca definicję przemocy: „Przemoc domowa zwana też przemocą w rodzinie to zamierzone i wykorzystujące przewagę sił działanie skierowane przeciw członkowi rodziny, które narusza prawa i dobra osobiste powodując cierpienie i szkody" ". Odnosząc to ujęcie do przemocy w związku bliskim/intymnym, można stwierdzić, że dochodzi do niej, gdy spełnione zostaną cztery warunki:

1. Intencjonalne działanie lub zaniechanie działania - świadome, celowe wyrządzanie krzywdy bądź zaniechanie niezbędnego dla poszanowania godności partnera działania.

2. Wyraźna przewaga jednej osoby nad druga - przemoc związana jest $\mathrm{z}$ bliską relacja, w której istnieje nierówny układ sił. Przewaga może wystąpić w dowolnej sferze na przykład fizycznej, psychicznej, materialnej, społecznej i jest wykorzystywana do podporządkowania partnera.

3. Naruszenie praw i dóbr osobistych partnera - oznacza przedmiotowe traktowanie, pomijanie potrzeb, życzeń, uczuć partnera.

4. Doświadczanie cierpienia i szkód przez osobe doznajaca przemo$c y$ - konsekwencje krzywdzenia mogą być wymierne lub nie, natychmiastowe lub odroczone, widoczne bądź niedostrzegalne.

Wśród form krzywdzenia wymienia się przemoc: fizyczną, psychiczną, emocjonalną, seksualną i materialną oraz zaniedbanie. Maltretowanie fizyczne łączy się z naruszeniem nietykalności sfery ciała i jego uszkodzeniem. Może przybierać różnorodne postaci takie jak: uderzenie, popychanie, gryzienie, kopanie, szarpanie, duszenie, oparzenie, ciągnięcie za włosy, ograniczenie swobody ruchów itp. Jeżeli dochodzi do złamania sfery intym-

${ }^{4}$ W. Badura-Madej, A. Dobrzyńska-Mesterhazy, Przemoc w rodzinie. Interwencja Kryzysowa i psychoterapia, Kraków 2000, s. 12.

${ }^{5}$ K. Browne, M. Herbert, Zapobieganie przemocy w rodzinie, Warszawa 1999, s. 31.

${ }^{6}$ H. D. Sasal, Niebieskie karty, Warszawa 1998, s. 17. 
ności poprzez zmuszanie do aktywności seksualnej, wówczas można mówić o przemocy seksualnej lub o wykorzystywaniu seksualnym. Wymienić tu można takie działania sprawcy jak: gwałt, pieszczoty, dotykanie narządów płciowych wbrew woli partnera, ale też poniżanie w sytuacjach intymnych, zmuszanie do oglądania obrazów o treści seksualnej etc.

Przemoc psychiczna jest zadawaniem cierpień poprzez kontrolowanie, ograniczanie i izolowanie ofiary. Przejawiać się może zastraszaniem, grożeniem wyrządzenia krzywdy, szantażowaniem, ciagłym niepokojeniem itp. Podobne metody krzywdzenia, które dotykają w sposób szczególny godność osobista, można odnaleźć w przemocy emocjonalnej. Sprawca krytykuje ofiarę, poniża ją, obraża, podważa poczucie własnej wartości, oczernia lub lekceważy itp. Z kolei przemoc ekonomiczna narusza prawo do dysponowania własnością, stawia ofiarę w stanie materialnej zależności. W praktyce oznacza to, że sprawca może pozbawiać ofiarę środków na utrzymanie, kontrolować jej wydatki czy niszczyć posiadane lub nabyte rzeczy. Innym rodzajem przemocy, często pomijanym, jest zjawisko zaniedbywania. Występuje ono w formie niewłaściwego wypełniania obowiązku opieki w stosunku do osób bliskich i może przybierać postać porzucania, pozbawiania pożywienia czy schronienia, nie udzielania pomocy w trudnościach czy chorobie?

Wszystkie opisane rodzaje przemocy są dotkliwe w skutkach. Niemniej, to przemoc psychiczna i emocjonalna, towarzysząc każdej innej formie przemocy, najbardziej zagraża godności, poczuciu wartości i mocy sprawczej człowieka, który tym aktom jest poddawany ${ }^{8}$. Z punktu widzenia zachowań osoby krzywdzącej w literaturze rozróżnia się także przemoc „,gorącą” i „chłodną”. Za podstawę przemocy „gorącej” uważa się furię - dynamiczne wyładowanie gniewu uruchamiające niebezpieczne zachowanie w formie bezpośrednich aktów przemocy fizycznej i psychicznej. Natomiast przemoc „,chłodna” pod maską spokoju widocznego dla obserwatora skrywa spiętrzone, silnie kontrolowane emocje. Sprawca, stopniowo realizując wyznaczony sobie cel, depcze granice psychiczne partnera, a dla swoich działań znajduje usprawiedliwienie $^{9}$, które, jak się okazuje, nie jest obce także partnerom sprawców.

\section{Mity i stereotypy związane z przemocą}

Chcąc ukryć, zatuszować czy zminimalizować problem, osoba doznająca przemocy, ale też pozostała część społeczeństwa, bazują często na po-

${ }^{7}$ K. Browne, M. Herbert, dz. cyt., s. 29-30.

${ }^{8}$ L. Alarcon Arias, A. Wiechcińska, W. Paszkiewicz, Godne życie bez przemocy. Poradnik dla osób stosujacych przemoc, Warszawa 2008, s. 13.

${ }^{9}$ L. Mellibruda, dz. cyt., s. 756. 
wierzchownych przekonaniach i stereotypach dotyczących zjawiska. Myślenie „na skróty” doprowadza do sytuacji powstrzymywania się od reakcji, odcinając jednocześnie ofiarę od możliwości poszukiwania pomocy. Zdarza się, że istniejące przekonania powodują poszukiwanie winy w samej osobie doznającej przemocy, przy jednoczesnym pomijaniu sfery odpowiedzialności, jaka leży po stronie sprawcy. Warto przedstawić niektóre z funkcjonujących w społeczeństwie do dnia dzisiejszego mitów i stereotypów, dotyczących przemocy, traktując je jako nieadekwatne i nieprawdziwe:

1. Maltretowanie to sprawa rodzinna. Negatywnymi skutkami tego przekonania jest powstrzymywanie się przed ingerencją w to, co się dzieje $\mathrm{w}$ rodzinie.

2. Nadużywanie alkoholu jest główna przyczyna przemocy. Alkohol może sprowokować zachowania krzywdzące, sam w sobie natomiast nie jest przyczyną przemocy. Nie ma gwarancji, że jeśli sprawca przestanie pić, maltretowanie ustanie.

3. Przemoc dotyczy rodzin patologicznych. Przemoc to jedno z najbardziej demokratycznych zjawisk w życiu społecznym. Występuje we wszystkich środowiskach i warstwach społecznych. Wykształcenie czy posiadany majątek nie odgrywają tu znaczącej roli.

4. Krzywdzenie nie może być aż tak straszne, bo inaczej ofiara by odeszła. Złożony układ czynników zamykający ofiarę w pułapce traumy silnie przeciwdziała odejściu od sprawcy.

5. Ofiara powinna wstydzić się, jeżeli jest maltretowana. Niezależnie od tego, jak zachowuje się osoba krzywdzona, to dręczyciel jest winny użycia przemocy.

6. Dla dobra dzieci powinno się znosić wszystko ze strony partnera. Nie ma wątpliwości, że przemoc jest dla dzieci negatywnym wzorcem. Nawet jeżeli znęcanie się nie występuje bezpośrednio w stosunku do dzieci, będąc świadkami przemocy, stają się jej ofiarami.

Przedstawiony szkic obiegowych opinii uzmysławia, jak wiele skutków negatywnych może mieć błędne myślenie czy też opieranie się na stereotypach. Bagatelizowanie problemu może stać się sposobem na zapewnienie sobie poczucia bezpieczeństwa poprzez niedopuszczanie do świadomości istnienia problemu. Warto pamiętać, że mity i stereotypy stanowią pierwszą, jakby zewnętrzną barierę uniemożliwiającą przerwanie spirali krzywd ${ }^{10}$.

Istnienie błędnych przekonań stawia przed osobami kompetentnymi szczególne zadania, polegające zwłaszcza na szeroko pojętej edukacji czy pedagogizacji społeczeństwa. Oddziaływanie edukacyjne pozwoliłoby na

${ }^{10}$ J. K. James, B. E. Gilliland, dz. cyt., s. 245-246; M. Lakowska, W. Paszkiewicz, A. Wiechcińska, dz. cyt., s. 21-26. 
zwiększenie świadomości istniejącego zjawiska w otoczeniu określonej osoby oraz pokazanie, jakie sposoby wsparcia czy reakcji byłyby najbardziej odpowiednie. Edukacja ma tutaj również duże pole działania w procesie przekazywania prawdziwych informacji na temat zjawiska i mechanizmów przemocy oraz weryfikowania istniejących dotychczas stereotypów w społeczeństwie.

\section{Proces wiktymizacji}

Reakcje społeczne odgrywają zasadnicza rolę w udzielaniu pomocy i wsparcia osobom doświadczającym traumy. Proces stawania się ofiarą jest rodzajem interakcji jednostka-otoczenie. U niektórych pokrzywdzonych zauważono występowanie charakterystycznych etapów prowadzących do przyjęcia tożsamości ofiary. Przede wszystkim powtarzające się akty maltretowania burzą istniejące do tej pory przekonania na temat świata i własnej osoby. Obniża się poczucie bezpieczeństwa, wykształca się natomiast negatywny obraz siebie, utrwalany przez sprawcę. W zachowaniu ujawniają się zachowania regresywne (infantylizacja zachowań), osoba zaczyna izolować się od ludzi. Następnym etapem jest tak zwany etap wtórnego zranienia. Brak reakcji z zewnątrz, nieudzielenie pomocy lub też zbagatelizowanie problemu sprawi, że osoba doświadczająca przemocy przyjmuje tożsamość ofiary. Charakteryzuje się to tym, że osoba przestaje się bronić przed doznawanymi atakami, pojawiają się myśli, że jest skazana na bycie ofiarą, przejmuje więc odpowiedzialność za doświadczaną przemoc poprzez piętnowanie siebie. W skrajnych przypadkach może dojść do podejmowania prób zamachu na własne życie. Trzeba zaznaczyć, że zjawisko wiktymizacji nie jest typowe dla wszystkich osób, wobec których stosowana jest przemoc. Pewne jest natomiast, że proces ten trafnie obrazuje destrukcyjny wpływ, jaki mają zachowania przemocowe na tożsamość ofiary ${ }^{11}$. Wsparcie ofiary przemocy mogłoby zawierać w sobie na przykład kategorie wsparcia emocjonalnego i wartościującego ${ }^{12}$, podnoszącego wartość własną osoby i jej samoocenę, uwalniającego z poczucia winy czy wyrzutów sumienia z powodu zaistniałej sytuacji.

${ }^{11}$ L. Mellibruda, dz. cyt., s. 759.

${ }^{12}$ S. Kawula, Spirala życzliwości: od wsparcia do samodzielności, „Wychowanie na co dzień” 10-11 (1996), s. 15. 


\section{Syndrom bitej kobiety}

Pozostawanie w związku, w którym dochodzi do maltretowania, jest uważane za sytuację stresową o charakterze chronicznym. Traumatyczne doświadczenie, jakim jest przemoc, zagraża nie tylko poczuciu integralności ciała, ale sieje również ogromne spustoszenie psychiczne. Permanentnie przeżywany stres w sytuacji przemocy diagnozuje się jako zaburzenia posttraumatyczne ${ }^{13}$, przy czym podkreśla się, że występują istotne różnice w intensywności i rodzajach symptomów u ofiar wydarzeń pojedynczego urazu (na przykład gwałt lub katastrofa) a ofiarami długotrwałej traumy, u których chroniczne objawy skutkują głębokimi zmianami w strukturze osobowości. Koncepcję zaburzeń stresu pourazowego wykorzystała L. Walter, tworząc pojęcie „syndromu kobiety maltretowanej" (battered women syndrome). W skład syndromu bitej kobiety wchodzą: niska samoocena, wycofanie z kontaktów społecznych i wyuczona bezradność ${ }^{14}$. Dodatkowymi objawami potęgującymi głębokość zmian obrazu osobowości są osiowe symptomy zespołu stresu pourazowego: osoba żyje w ciagłym napięciu, które jest efektem strachu, że trauma się powtórzy. Skrzywdzenie powraca pośrednio poprzez natrętne wspomnienia, nawracające sny, przykre emocje, pojawiające się w zetknięciu z sytuacjami przypominającymi uraz. W sferze zachowań zauważa się pobudzenie i wzmożoną czujność. Nierzadkie są zaburzenia psychosomatyczne czy zaburzenia snu. Według J. L. Herman, najbardziej wyrazistym elementem zespołu jest unikanie czy zawężenie. Mechanizmy te początkowo służą psychicznej adaptacji i przeżyciu. Długotrwałe zawężenie tłumi zdolności psychiczne, prowadząc do nadmiernej koncentracji na życiu wewnętrznym. Okoliczności te sprawiają, że osoba czuje się odrętwiała, obca, następuje spadek jej zainteresowań codziennymi aktywnościami. Jednocześnie czyni ona ogromny wysiłek psychiczny, by unikać wszelkich myśli, uczuć, aktywności przypominających uraz. Natrętne unikanie i jednoczesne powracanie traumy pod symboliczną postacią zaburza homeostazę emocjonalną, poznawczą i behawioralną. W każdej z tych sfer mogą wystapić reakcje przesadne, niekiedy nieprzewidywalne ${ }^{15}$. Na już wytworzony syndrom nakładają się powtarzające się akty krzywdzenia, co dodatkowo osłabia siły ofiary, zwiększa jej wrażliwość na kolejne zranienie. Konstelacja

${ }^{13}$ Według klasyfikacji DSM-IV- zespół stresu pourazowego PTSD, cyt. za: I. Rajska-Kulik, Przemoc wewnatrzmatżeńska - uwarunkowania pozostawania maltretowanych kobiet w krzywdzacym zwiqzku, „Chowanna” 1/28 (2007), s. 14.

${ }_{14}$ W. Badura-Madej, A. Dobrzyńska-Mesterhazy, dz. cyt., s. 23-24.

15 Tamże, s. 23-24; J. L. Herman, Przemoc. Uraz psychiczny i powrót do równowagi, Gdańsk 2007, s. 97-101. 
czynników syndromu bitej kobiety prowadzi do wystąpienia cech klinicznej depresji. Tłumione uczucia, a przede wszystkim fakt rzadkiego wyrażania gniewu przez osoby krzywdzone, w połączeniu ze skłonnością do samoobwiniania się prowadzą do zachowań autodestrukcyjnych ${ }^{16}$.

W artykule szczególną uwagę poświęcono przemocy w związkach, gdzie ofiarą jest kobieta, a sprawcą mężczyzna. Takie ujęcie problemu wynika $\mathrm{z}$ faktu, że tematowi przemocy wobec partnera mężczyzny literatura przedmiotu poświęca znacznie mniej uwagi. Zaproponowany przez S. K. Steinmetz „zespół bitego męża” (battered husband syndrome) nie uzyskał aprobaty naukowców z uwagi na brak dowodów, jakoby znęcanie się partnerki wywoływało u mężczyzny zespół symptomów podobny do syndromu bitej kobiety ${ }^{17}$. Praktyka pokazuje jednak, że maltretowani mężczyźni wykazują zbliżone do doznających przemocy kobiet objawy. W sytuacji stawania się ofiarą przemocy potrzebują więc oni podobnego oddziaływania interwencyjnego, a także wsparcia.

\section{Wyuczona bezradność}

Syndrom bitej kobiety według L. E. Walker rozwija się dwufazowo. Na początku ofiara buntuje się czynnie lub biernie. Kiedy metody te okazują się nieskuteczne, partner nadal maltretuje, a w osobie krzywdzonej wytwarza się poczucie bezsilności często wraz ze współistniejącą depresją. Stan taki określono mianem wyuczonej bezradności. Seligman, będący twórcą tej koncepcji, dowiódł, że powtarzający się uraz doprowadza do apatii i bierności, którym towarzyszą deficyty motywacji i zakłócenia rozwiązywania problemów. Osoby doznające przemocy charakteryzują się specyficznym stylem ,atrybucyjnym”; swoim cechom, zachowaniom przypisują odpowiedzialność za zachowanie sprawcy. Wierza, że to one prowokują ataki. Tego rodzaju wewnętrzne atrybucje są stałe i dotyczą całości funkcjonowania osoby, przez co predysponują do chronicznej bezradności ${ }^{18}$. Zniekształcone atrybucje dotyczą również osoby sprawcy i są przeciwieństwem spostrzegania siebie. W. Frude stwierdza, że mają one ograniczony zasięg („Pod innymi względami on jest w porządku”), są nietrwałe („Tylko czasem się upija”), a w poszukiwaniu przyczyny skierowane są na zewnątrz (,Bije tylko wtedy, gdy jest pijany. Wiem, że jestem dla niego ważna”). Internalizacja poczucia winy u ofiary wywołuje niemoc, ograniczając strategie radzenia

\footnotetext{
16 I. Rajska-Kulik, dz. cyt., s. 15.

17 K. Browne, M. Herbert, dz. cyt., s. 79.

18 I. Rajska-Kulik, dz. cyt., s. 16-17.
} 
sobie $^{19}$. Dalsze badania dowiodły jednak, że kobiety nie są wyłącznie bierne i bezwolne. Zmieniaja jedynie strategie działania na takie, które pozwola im przetrwać, zmniejszą ryzyko ataku, zapewnią minimum bezpieczeństwa jak na przykład: unikanie partnera, by nie wpadł w złość, bycie posłuszną i ustępliwą ${ }^{20}$.

\section{Cykle nadużyć}

Obserwacja przebiegu interakcji sprawca-ofiara doprowadziła do stwierdzenia, że rozwojowi przemocy towarzyszą cyklicznie zachodzące zdarzenia. Wyróżnia się wśród nich: fazę narastania napięcia, fazę ostrej przemocy i fazę wyrzutów sumienia i tymczasowego powrotu miłości (okres miodowego miesiąca) ${ }^{21}$.

W pierwszym etapie wyczuwa się wzrost napięcia. Partner staje się dysforyczny, spięty. Awanturę wszczyna każdy drobiazg, sprawca sprawia wrażenie, jakby nie kontrolował złości. W tym czasie może nadużywać substancji psychoaktywnych. Osoba krzywdzona stara się wówczas opanować sytuację uspokajając, przepraszając, dogadzając zachciankom partnera, jednocześnie usprawiedliwiając go niekorzystnymi czynnikami zewnętrznymi. Bywa, że ofiara odczuwa w tej fazie dolegliwości psychosomatyczne, jest apatyczna i niespokojna. Zdarza się, że w momencie, gdy napięcie staje się nie do wytrzymania, ofiara sama prowokuje kłótnię, by doprowadzić do wyładowania emocji. W ten sposób dochodzi do fazy ostrej przemocy. Zachowanie sprawcy staje się gwałtowne, czasem wpada w amok, zgromadzone napięcie zostaje eksplozywnie wyładowane na partnerze. Zarówno przemoc werbalna, jak i fizyczna osiagaja punkt kulminacyjny i z tego względu ta faza jest najbardziej niebezpieczna dla zdrowia i życia ofiary. Osoba krzywdzona stara się załagodzić sytuację wszelkimi dostępnymi jej strategiami. Nic jednak nie jest w stanie powstrzymać napastnika, czego konsekwencją jest mieszanina smutku, wstydu, złości i bezradności ofiary ${ }^{22}$.

Silne wyładowanie emocji może uświadomić sprawcy, że przekroczył granice. Stara się odzyskać przychylność partnera: przeprasza, składa obietnice, że sytuacja się nie powtórzy, okazuje skruchę i miłość - dba o ofiarę, przynosi kwiaty, prezenty itp. Z tej przyczyny osoba skrzywdzona odzyskuje nadzieję, spostrzegając zajście jako incydent. Faza ta niesie za sobą naj-

\footnotetext{
19 K. Browne, M. Herbert, dz. cyt., s. 88-89.

20 I. Rajska-Kulik, dz. cyt., s. 17.

21 J. K. James, B. E. Gilliland, dz. cyt., s. 247.

${ }^{22}$ M. Lakowska, W. Paszkiewicz, A. Wiechcińska, dz. cyt., s. 56-57.
} 
większe zagrożenie, gdyż niebawem rozpocznie się kolejny cykl, w którym przemoc będzie gwałtowniejsza. Cykle krzywdzenia mogą trwać latami, co charakterystyczne, z upływem czasu fazy miodowego miesiąca skracają się na poczet wydłużenia dwóch pierwszych etapów. $Z$ czasem pozostają tylko faza narastania napięcia i ostrej przemocy ${ }^{23}$.

\section{Zjawisko „prania mózgu”}

Pozostawanie w krzywdzącym związku w znacznej mierze opiera się na mechanizmach zniewolenia psychicznego. Jak wspomniano na wstępie, przemoc psychiczna i emocjonalna towarzyszą każdemu z rodzajów znęcania się. W odniesieniu do jej występowania w związkach przyjęło się określenie „małżeński terror”24. Termin ten należałoby jednak interpretować w kategoriach szerszych niż wskazywałby na to zakres znaczeniowy pojęcia, odnoszący je jedynie do par małżeństw. Oznacza to, że przedstawione mechanizmy są charakterystyczne także dla nieformalnych związków dwojga ludzi, w których stosowana jest przemoc. W literaturze anglojęzycznej stosuje się określenie intimate partner violence (przemoc w bliskich/intymnych związkach) w odniesieniu do ,sytuacji przemocy między osobami (heteroseksualnymi lub homoseksualnymi), które pozostają w bliskim związku (formalnym lub nieformalnym) bądź uważają siebie za parę, nie mieszkając ze sobą" 25 .

Następujący w przemocy proces zniewalania psychicznego nazywany jest w literaturze ,praniem mózgu”. Korzenie zjawiska sięgają metod stosowanych wobec jeńców w krajach totalitarnych, których celem było uzyskanie władzy nad psychiką i zachowaniem więźnia, tak by przejął on ideologię prześladowcy. Podobnie jest w krzywdzącym związku. Partner próbuje osiągnąc kontrolę poprzez: izolację ofiary, poniżenie i degradowanie jej, monopolizowanie jej uwagi, groźby i demonstrowanie siły, chwilowe okazywanie pobłażliwości ${ }^{26}$.

Pierwszym krokiem na drodze zniewolenia psychicznego jest izolacja społeczna. Odcięcie od źródeł wsparcia następuje poprzez kontrolowanie i ograniczanie kontaktów ofiary. Krytykowanie i obrażanie rodziny oraz znajomych ofiary, karanie za próby ujawnienia tego, co dzieje się w domu, to jedne z metod osiągnięcia celu przez sprawcę. W ten sposób władza dręczy-

23 Tamże, s. 58.

24 W. Badura-Madej, A. Dobrzyńska-Mesterhazy, dz. cyt., s. 16.

25 M. Makara-Studzińska, A. Grzywa, R. Turek, Przemoc w zwiqzkach między kobieta a mężczyznq, „Postępy Psychiatrii i Neurologii” 14/2 (2005), s. 131.

26 L. Mellibruda, dz. cyt., s. 760. 
ciela rozciaga się, a partner pozostaje osamotniony w cierpieniu. Zaprzestanie komunikacji z otoczeniem sprawia, że sprawca jest jedyną osobą dostarczająca osobie krzywdzonej informacji na jej temat. Krytykując, poniżając doprowadza do zaniku poczucia atrakcyjności, drastycznie obniża samoocenę. Wreszcie ofiara zaczyna się obwiniać za doznawaną przemoc. Z czasem znęcający się wymaga bezwzględnego posłuszeństwa. Jego myśli, uczucia i zachowania są punktem odniesienia dla ofiary. W efekcie zapomina ona o własnych potrzebach, jej funkcjonowanie zawęża się do przewidywania działań sprawcy i prób przygotowania się na ataki. Zjawiskom tym towarzyszą groźby, demonstracja siły, które nawet bez stosowania przemocy fizycznej są w stanie wymusić posłuszeństwo. Niektóre z gróźb bywają spełniane, stąd ofiara nie może przewidzieć, co tak naprawdę zrealizuje dręczyciel. Od czasu do czasu sprawca zmienia postępowanie - okazuje czułość, zapomina o wymaganiach, co (podobnie jak w fazie miodowego miesiąca) daje ofierze złudną nadzieję, że partner się zmieni.

„Pranie mózgu” przejrzyście pokazuje, że przyjęcie takiej rzeczywistości, jaką kreuje sprawca, łatwo doprowadza do drastycznych zmian w obrazie siebie ofiary. Nieustannie przeżywany lęk i poczucie winy, osłabiają zdolności przeciwstawienia się przemocy, wyczerpują ${ }^{27}$. Pokazuje również, jak bardzo ważne w tym przypadku byłoby udzielane wsparcie, rozumiane tutaj jako ,pomoc dostępna w sytuacjach dla jednostki trudnych, stresowych, przełomowych, a których bez wsparcia innych nie są w stanie przezwyciężyć" 28 . Nie ulega wątpliwości, że osoba doświadczająca przemocy jest osoba, która tego rodzaju wsparcia potrzebuje. Mogłoby ono przybierać postać rozmowy z ofiarą o nieponoszeniu winy za dziejącą się sytuację. Innym rodzajem byłoby wsparcie instrumentalne i informacyjne, polegające na wskazaniu odpowiedniego miejsca, gdzie ofiara byłaby bezpieczna oraz kroków, które należałoby wykonać dla znalezienia dla siebie pomocy. W tej kategorii wsparcia mieściłoby się także dostarczanie konkretnej pomocy, na przykład dostarczanie ubrania, wskazanie form leczenia, jeśli ofiara tego potrzebuje. To również udzielanie rad prawnych, medycznych, niezbędnych w sytuacjach doświadczania przemocy i przeciwdziałania jej trwaniu. Czasem ofiara przemocy wymagałaby wykonania tych czynności za nią. Kolejnym rodzajem wsparcia byłoby wspomniane wcześniej wsparcie emocjonalne i wartościujące podnoszące wartość osoby jako człowieka, znajdowanie zasobów, z których mogłaby osoba korzystać przy wracaniu do równowagi emocjonalnej i psychicznej ${ }^{29}$. Efektem wsparcia miałaby być próba ukształ-

\footnotetext{
27 Tamże, s. 760; M. Lakowska, W. Paszkiewicz, A. Wiechcińska, dz. cyt., s. 65-66.

${ }^{28}$ S. Kawula, dz. cyt., s. 15.

${ }^{29}$ Rodzaje wsparcia społecznego cyt. za: S. Kawula, dz. cyt., s. 15.
} 
towania samodzielności i zdolności radzenia sobie w konkretnych sytuacjach poprzez nauczenie odpowiednich niezbędnych umiejętności ${ }^{30}$.

\section{Syndrom sztokholmski}

Dla obserwatora paradoksem może być niezwykle silna więź łącząca osobę krzywdzoną z jej dręczycielem. Aby wyjaśnić ten związek, D. Graham i E. I. Rawlings przywołali koncepcję zespołu sztokholmskiego, polegającego na wytworzeniu szczególnego przywiązania i identyfikacji zakładników z terrorystami. F. M. Ochberg związek ten określił jako „paradoksalna więź”, zaś D. Dutton nazwał go „więzią traumatyczną"31. J. L. Herman twierdzi nawet, że: „żadna relacja nie jest równie intensywna jak patologiczna więź z prześladowca" "32. Jak do tego dochodzi? Nie bez związu pozostaje oczywiście zjawisko „prania mózgu”, doprowadzające do absurdalnej fascynacji oprawca. Z punktu widzenia ofiary, partner ma całkowitą władzę nad jej życiem, w związku z czym odczuwa ona bezsilność, izolację, ograniczenie kontaktów, nieustanną kontrolę oraz upokarzanie, które ostatecznie wiodą do totalnej zależności. W tej sytuacji sprawca przemocy staje się władca, a wszelkie odruchy dobroci z jego strony odbierane są przez ofiarę z wdzięcznością. Ofiara jest wdzięczna za wszystko, co mógłby sprawca zrobić a nie zrobił dzięki „swojej łaskawości.” Implikacją przedstawionych mechanizmów jest swego rodzaju infantylizacja, regresja osoby krzywdzonej, będące kluczem do identyfikacji ze sprawcą ${ }^{33}$.

\section{Efekt ,pulapki psychologicznej”}

Pewnym zestawieniem opisanych mechanizmów, utrzymujących ofiarę przy oprawcy, są opisane przez M. J. Stube motywy trwania w krzywdzącej relacji ${ }^{34}$ :

1. „Pułapka psychiczna” - opiera się na spostrzeganiu przez osobę doznająca przemocy własnych inwestycji (czas, energia, wypracowane strategie postępowania etc.) w celu utrzymania związku. Ważąc te czynniki,

${ }^{30}$ A. Olubiński, Wsparcie spoleczne w pracy socjalno-wychowawczej. Zarys problematyki, w: „Wychowanie na co dzień” 10-11 (1996), s. 20.

${ }^{31}$ W. Badura-Madej, A. Dobrzyńska-Mesterhazy, dz. cyt., s. 26.

32 J. L. Herman, dz. cyt., s. 102.

${ }^{33}$ W. Badura-Madej, A. Dobrzyńska-Mesterhazy, dz. cyt., s. 26.

${ }^{34}$ I. Rajska-Kulik, dz. cyt., s. 21. 
uświadamia sobie, ile ma do stracenia. Gdyby odeszła, jej zaangażowanie poszłoby na marne.

2. „Pułapka lęku” - lęk jest towarzyszem osób doznających przemocy, zarówno gdy cierpią, jak i wtedy, gdy rozważają rozstanie. To drugie paraliżuje mocniej - rodzi wyolbrzymione obawy przed nieznanym ${ }^{35}$.

3. „Pułapka sytuacyjna” - osoba krzywdzona dokonuje bilansu zysków i strat, będąc w przekonaniu, że znalazła się w sytuacji patowej. Szacuje, że pozytywne strony trwania w związku przewyższają korzyści z odejścia. Sądzi się, że taki styl myślenia dotyczy głównie relacji, w której przemoc występuje rzadko i może być wówczas postrzegana jako mniejsze zło.

4. Pułapka powiązana z wyuczoną bezradnością - przekonanie ofiary, że sama nie ma wpływu na bieg zdarzeń, implikuje rezygnację, porzucenie prób wyjścia z kręgu przemocy na rzecz wytworzenia strategii pozwalających przetrwać ${ }^{36}$.

Pułapki przemocy są tak silne, że połowa poszukujących pomocy osób kontynuuje relację z opresorem, a 34\% tych, które wracają do domu, w dalszym ciagu doświadcza cierpienia. N. Frude uchwycił charakterystyczne cechy kobiet, które opuszczają dręczyciela, a następnie do niego wracają. Cztery razy większe prawdopodobieństwo powrotu zanotowano u osób, które: doświadczały przemocy rzadko i w mniejszym nasileniu, w swej historii mają mniej separacji, miały rzadki kontakt z organami ścigania i ośrodkami sprawującymi opiekę nad dziećmi, są bezrobotne i/lub zależne finansowo, ich pobyt w schronisku dla kobiet był krótki i od początku nosiły się z zamiarem powrotu ${ }^{37}$.

\section{Zakończenie}

Bez wątpienia pozostawanie w krzywdzącym związku jest zachowaniem polimotywacyjnym. Konstelacja zamykających na poszukiwanie pomocy mechanizmów utrzymuje osobę doznająca przemocy w pułapce. W skrajnych przypadkach subiektywne spostrzeganie traumatycznej sytuacji przez ofiarę jest zawężone do codziennego radzenia sobie w oparciu o strategie przetrwania. Naturalnie, życie pisze mocno zindywidualizowane historie, w których poszczególne czynniki decydujące o byciu z oprawcą wysuwają się na plan pierwszy. Pewne jest, że stan współczesnej wiedzy nie uprawnia

${ }^{35}$ R. J. Ackerman, S. E. Pickering, Zanim będzie za późno. Przemoc i kontrola w rodzinie, Gdańsk 2002, s. 41.

${ }^{36}$ I. Rajska-Kulik, dz. cyt., s. 22.

${ }^{37}$ K. Browne, M. Herbert, dz. cyt., s. 90. 
do poszukiwania przyczyn znęcania w składowych osobowości ofiary, brak jest dowodów na istnienie tego rodzaju cech. Wyjątek powiązania z wiktymizacją stanowi niższe poczucie własnej wartości oraz fakt obserwowania przemocy w dzieciństwie ${ }^{38}$.

Opisane zjawisko przemocy i mechanizmy z nią związane są konsekwencją patologizacji więzi interpersonalnej. Zachowania przemocowe naruszają homeostazę $\mathrm{w}$ związku na rzecz deprecjacji kardynalnych potrzeb krzywdzonego partnera ${ }^{39}$. Gdyby zaś pokusić się o sprowadzenie owych potrzeb do wspólnego mianownika, można by określić je mianem godności oraz autonomii osobistej. Uderzenie $\mathrm{w}$ te niezbywalne i przynależne każdemu człowiekowi prawa stanowi kwintesencję uwięzienia w nasyconym przemocą związku ${ }^{40}$.

\section{Violence and its Workings in Unmarried Relationships (Summary)}

Violence has been around with man since time forgotten and it is a common phenomenon in every area of life. Violence becomes especially harmful when it occurs between two persons who are in a close relationship. Although the issue of violence in unmarried relationships appears to have been discussed abundantly in the literature, the knowledge of the subject needs to be constantly updated and renewed because victims of violence too often tend to keep their predicament secret. The article presents basic information regarding the issue in question and describes forms of violence which may occur between a victim and perpetrator. The article also points to socially rooted stereotypes which hinder an injured party from seeking help. The authors describe all the typical characteristics of an abused woman, her thoughts which she is overcome by, her feelings and behaviour in an ever-growing spiral of violence. An exploration of the phenomenon of violence may assist in raising the social awareness of the problem, and thus it possesses an educational value. Such knowledge helps provide more adequate emotional, instrumental, informational and appraisal support to a person exposed to violence when she is not able to cope with the situation herself.

${ }^{38}$ S. D. Herzberger, Przemoc domowa. Perspektywa psychologii społecznej, Warszawa 2002, s. 80 .

39 B. Hołyst, Psychologia kryminalistyczna, Warszawa 2006, s. 420-421.

${ }^{40}$ M. Lakowska, W. Paszkiewicz, A. Wiechcińska, dz. cyt., s. 27-30. 